\title{
Contemporary Challenges to the Organic Farming: A Polish and Hungarian Case Study
}

\author{
Anna Mazurek-Kusiak, Bogusław Sawicki and Agata Kobyłka *(D) \\ Department of Tourism and Recreation, University of Life Sciences in Lublin, 20-950 Lublin, Poland; \\ anna.mazurek@up.lublin.pl (A.M.-K.); boguslaw.sawicki@up.lublin.pl (B.S.) \\ * Correspondence: agata.kobylka@up.lublin.pl
}

Citation: Mazurek-Kusiak, A.;

Sawicki, B.; Kobyłka, A.

Contemporary Challenges to the Organic Farming: A Polish and Hungarian Case Study. Sustainability 2021, 13, 8005. https://doi.org/ $10.3390 /$ su13148005

Academic Editor: Antonio Boggia

Received: 19 June 2021

Accepted: 14 July 2021

Published: 17 July 2021

Publisher's Note: MDPI stays neutral with regard to jurisdictional claims in published maps and institutional affiliations.

Copyright: (c) 2021 by the authors. Licensee MDPI, Basel, Switzerland. This article is an open access article distributed under the terms and conditions of the Creative Commons Attribution (CC BY) license (https:// creativecommons.org/licenses/by/ $4.0 /)$.

\begin{abstract}
From year to year, there is an increasing demand for agricultural produce from certified organic farms. However, Poland and Hungary's demand for this product is almost twenty times smaller than in Western European countries. The greater the demand by consumers for organic farming products, the more agricultural producers decide to switch from conventional farming to organic farming, and this farming is more environmentally friendly because it uses energy and natural resources responsibly, maintains biodiversity, maintains regional ecological balance, improves soil food, and maintains good water quality. This research aimed to compare the motives and barriers to running organic farms in Poland and Hungary, and the challenges farmers must face to undertake the trouble of running an organic farm. The research was carried out among 400 Polish and 400 Hungarian farmers running organic farms. For statistical calculations, discriminant analysis, as well as single-base and chain indices, were used. The main barriers for establishing organic farms: the necessity to adapt one's farm to the EU requirements, using only natural fertilizers, low yields, the lack of proper advice, and a high degree of bureaucracy. Therefore, for organic farming to develop, further education is needed, both for farmers and consumers. An important aspect is improving the quality of the regulations and simplifying the administrative burden related to organic farming.
\end{abstract}

Keywords: organic farming; certification; motives and barriers; organic food; Poland; Hungary

\section{Introduction}

Fifty-three percent of human health depends on diet, $21 \%$ on the quality of the natural environment, $16 \%$ on genetic heritage, and $10 \%$ on the effectiveness of the health service [1]. Each year, consumers introduce about $2.5 \mathrm{~kg}$ of chemical compounds derived from food into their bodies [2], including 70-80\% heavy metals such as lead, cadmium, mercury, and herbicides. Therefore, every year there is an increasing demand for agricultural produce from certified organic farms. The value of the Polish organic food market is estimated at EUR 31 million, and the Hungarian market at EUR 30 million. This represents 0.5\% of the total food market. For three years, the market has been growing at a rate of about $10 \%$. Thus, the average Polish and Hungarian consumer spends around EUR 8 per year on eco-products [3-7]. This is also confirmed by research, including Danner and Menapac [8], Boizot-Szantai [9], and Dash and Dash [10], among others. As many as 52\% of Western European consumers choose organic products, even if it means an additional cost for them [11]. In 2014, in Poland, as in Hungary and Romania, the expenditure on organic food was around EUR 4 per person. For comparison, in Switzerland, consumers spent EUR 189, in the Netherlands EUR 158, in Germany EUR 86, and in France EUR 61 [12]. Organic farm products are also beginning to gain importance in the former socialist countries, but the changes are slow [11]. For example, in 2013, Poles spent about PLN 650-700 million on organic products, and three years earlier, only PLN 200 million [13,14]. The fashion and awareness of healthy eating make consumers from Central and Eastern Europe more and more willing to buy bioproducts [11]. Consequently, they more and more often verify the 
composition of food products, their origin, and the methods of their production, making sure that organic methods were used in their production [14], although their scale is almost twenty times smaller than in other Western European countries. It is often believed among consumers from the former socialist bloc that organic farming products are expensive. However, the price differences between conventional and organic food are slowly decreasing. Therefore, education is needed to make bioproducts more recognizable. It should be remembered that the greater the demand by consumers for organic farming products, the more agricultural producers decide to switch from conventional farming to organic farming [15], and it should be remembered that organic farming is more environmentally friendly. It uses energy and natural resources responsibly, maintains biodiversity, maintains regional ecological balance, improves soil food, maintains good water quality, creates new jobs, and attracts young farmers [11,14]. Organic farming contributes to sustainable development and increases interest in rural areas [16]. Therefore, it is worth reducing the shares of conventional farms favoring organic farms [11].

In 2019, almost 12.5 million hectares of the 156.7 million hectares dedicated to agriculture were allocated to organic farming in the European Union, i.e., $8 \%$ of the total area. However, the European "Farm to Fork" strategy aims to devote 25\% of the agricultural area, i.e., 39.2 million hectares, to organic production by 2030 [17]. The most considerable amount of arable land intended for organic production is recorded in the wealthiest countries of Western Europe, i.e., in Spain (2.4 million ha), France (2.2 million ha), Italy (1.9 million ha), and Germany (1.3 million ha) [18]. These countries also have the most significant number of organic farms: 41 thousand, 37 thousand, 71 thousand, and 34 thousand, respectively. The largest shares of agricultural land devoted to organic farming are found in Austria (24.6\%), Estonia $(23.1 \%)$, Sweden $(20.2 \%)$, and Italy $(16.5 \%)[19,20]$. The situation is much worse in Poland and Hungary, where this percentage is $3.5 \%$ and $6.5 \%$, respectively. In Poland, organic production takes up only 0.5 million ha, and in Hungary, even less- 0.3 million ha. There are 18.6 thousand farms in Poland and 5.1 thousand in Hungary [21]. Thus, it can be concluded that in both countries, organic farming remains a niche market. The problem in these countries is that Polish and Hungarian organic farming is mainly a basin of organic raw materials exported to Germany, France, and Italy and then imported to Poland and Hungary in the form of finished products [22-24]. The state of ecological awareness and the threats posed by the degradation of the natural environment for the conditions and quality of life affect the motivation system of some Polish and Hungarian farmers. However, the willingness to establish farms is much lower than in Western European countries.

To close this discrepancy, it is crucial to understand the motives and barriers to running organic farms. Economic, not ecological, criteria guide most farmers in their choices. Still, producers whose ecological awareness changes and willingly choose production technologies do not harm the natural environment [25].

This research aimed to compare the motives and barriers to running organic farms in Poland and Hungary, as well as the challenges farmers must face to undertake the trouble of running an organic farm. The research applied the method of a diagnostic survey. The research was carried out among 400 Polish and 400 Hungarian farmers running organic farms. The differences between the motives and barriers of running organic farms by Polish and Hungarian farmers were examined using discriminant analysis.

\section{Materials and Methods}

\subsection{Context}

A comparative analysis was performed in two countries of Central and Eastern Europe because these countries are similar to each other, have a similar history, tradition, and models of consumer behavior. In both countries, until the 1950s, agriculture maintained the 19th-century agricultural production system, used the advantages of the economy rotationally, and used positive feedback loops between plant and animal production. After World War II, they functioned in a centrally controlled economy until 1989, and then adopted the market economy system. In both countries, organic farming plays the role 
of a niche market. In Poland and Hungary, farms are fragmented; the average area is approximately 9 ha. However, in Hungary, during the socialist period, 90\% of farms were owned by production cooperatives [26]. In Poland, this percentage was only $23.8 \%$; the remaining $76.2 \%$ of farms were in private hands [27]. At the beginning of the 1990s, 2.2 million private farms with an area of 3-4 ha were established in both Poland and Hungary [28]. However, most of the new Hungarian agricultural producers did not have the appropriate expertise, experience, capital base, agricultural machinery, and premises in buildings. Hungarian farmers leased the means of production or sold or rented agricultural land, while Polish farmers had more experience and machinery on their farms [27].

The Common Agricultural Policy of the EU was launched in 1962, and its primary goal is to ensure food independence for EU inhabitants, including access to high-quality food, and to contribute to the achievement of sustainable development goals, including the preservation of land resources, water in good condition, air quality, and biodiversity for future generations. In addition, it is to ensure a decline in the price of agricultural products, strengthen the position of farmers in the market chain, and ensure the distribution of effects (benefits and costs) between the Member States and sectors of the economy, resulting from new trade agreements concluded by the EU. Developing countries should also receive a higher level of support [5].

In 2012-2019, more than 1.1 million tons of organic crops were produced in Hungary. Observing the single-base indices, a general upward trend can be seen relating to the condition of 2012, which was adopted as the basis for comparisons. Agricultural production increased relatively in 2019 by 116.5 thousand tons, i.e., by as much as $121.1 \%$ compared to the base year. This increase was due to the increase in the number of farms, the number of hectares devoted to organic farming, and more favorable selling prices of agricultural produce (Table 1).

Table 1. Organic agricultural production on Hungarian farms in 2012-2019.

\begin{tabular}{|c|c|c|c|c|c|c|}
\hline \multirow[b]{2}{*}{ Year } & \multirow{2}{*}{$\begin{array}{c}\text { Organic } \\
\text { Agricultural } \\
\text { Productionin Tons }\end{array}$} & \multicolumn{2}{|c|}{ Absolute Increase (n) } & \multicolumn{2}{|c|}{ Relative Increase (in \%) } & \multirow{2}{*}{ 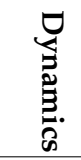 } \\
\hline & & $\begin{array}{c}\text { Single-Base } \\
\text { Indices } 2012=100\end{array}$ & Chain Indices & $\begin{array}{c}\text { Single-Base } \\
\text { Indices } 2012=100\end{array}$ & Chain Indices & \\
\hline 2012 & 96,214 & & & & & \\
\hline 2013 & 119,596 & 23,382 & 23,382 & 24.3 & 24.3 & 1.243 \\
\hline 2014 & 126,978 & 30,764 & 7382 & 32.0 & 6.2 & 1.062 \\
\hline 2015 & 104,141 & 7927 & $-22,837$ & 8.2 & -18.0 & 0.820 \\
\hline 2016 & 116,178 & 19,964 & 12,037 & 20.7 & 11.6 & 1.116 \\
\hline 2017 & 132,460 & 36,246 & 16,282 & 37.7 & 14.0 & 1.140 \\
\hline 2018 & 196,424 & 100,210 & 63,964 & 104.2 & 48.3 & 1.483 \\
\hline 2019 & 212,692 & 116,478 & 16,268 & 121.1 & 8.3 & 1.083 \\
\hline $\begin{array}{c}\text { annually on } \\
\text { average }\end{array}$ & 138,085 & & & & annually on average & 1.120 \\
\hline
\end{tabular}

Source: own study based on [20].

Organic agricultural production in the analyzed period increased on average by $12.0 \%$ annually. However, it should be noted that in 2015, there was a decrease in organic agricultural production compared to 2014 by 22.8 thousand tons, i.e., by $18.0 \%$, and since 2016, there has been an increase from year to year (Table 1). This decrease resulted from the change in the regulations on the procedure and principles of granting financial aid from EU funds to organic food producers.

In 2012-2019, 2.8 million tons of organic agricultural products were produced in Poland, i.e., 2.5 times more than in Hungary. Over the years of 2012-2019, the absolute increase amounted to 618.6 thousand tons, i.e., as much as 6.4 times. From year to year, 
there was an increase in organic agricultural production, although the pace of changes varied from year to year. The most significant increase took place between 2018 and 2019, by as much as $38.1 \%$. Between 2017 and 2018, this increase was $25.0 \%$. The smallest increase was observed between 2014 and 2015, at only 5.2\%. At that time, in Hungary, there was a decrease in organic agricultural production by as much as $18.0 \%$. The low increase in organic production was due to the decrease in the number of organic farms caused by the instability of legal regulations, multiple updates of the procedures for granting subsidies for organic production, and the modification of the IT system of the Agency for Restructuring and Modernization of Agriculture in Poland, which resulted in delays in issuing decisions on granting subsidies and paying out money to organic producers. In Poland, on average, organic agricultural production grew by $17.2 \%$ (Table 2 ).

Table 2. Organic agricultural production on Polish farms in 2012-2019.

\begin{tabular}{|c|c|c|c|c|c|c|}
\hline \multirow{3}{*}{ Year } & \multirow{3}{*}{$\begin{array}{c}\text { Organic } \\
\text { Agricultural } \\
\text { Production in Tons }\end{array}$} & \multicolumn{2}{|c|}{ Absolute Increase (n) } & \multicolumn{2}{|c|}{ Relative Increase (in \%) } & \multirow{3}{*}{ 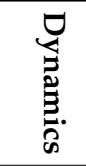 } \\
\hline & & Single-Base Indices & Chain & Single-Base Indices & Chain Indice & \\
\hline & & $2012=100$ & Indices & $2012=100$ & 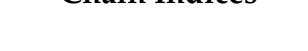 & \\
\hline 2012 & 235,543 & & & & & \\
\hline 2013 & 260,936 & 164,722 & 25,393 & 171.2 & 10.8 & 1.108 \\
\hline 2014 & 290,023 & 193,809 & 29,087 & 201.4 & 11.1 & 1.111 \\
\hline 2015 & 305,062 & 208,848 & 15,039 & 217.1 & 5.2 & 1.052 \\
\hline 2016 & 355,199 & 258,985 & 50,137 & 269.2 & 16.4 & 1.164 \\
\hline 2017 & 414,062 & 317,848 & 58,863 & 330.4 & 16.6 & 1.166 \\
\hline 2018 & 517,472 & 421,258 & 103,410 & 437.8 & 25.0 & 1.250 \\
\hline 2019 & 714,842 & 618,628 & 197,370 & 643.0 & 38.1 & 1.381 \\
\hline $\begin{array}{c}\text { annually on } \\
\text { average }\end{array}$ & 386,642 & & & & annually on average & 1.172 \\
\hline
\end{tabular}

Source: own study based on [20].

Both Hungary and Poland produce the most organic cereals intended for industry, $49.6 \%$ and $41.0 \%$, respectively. In Hungary, fruits from the temperate climate zone came second $(11.9 \%)$, and organic vegetables came third (11.6\%). On the other hand, in Poland, winter cereals came second $(15.6 \%)$, and fruit from the temperate climatic zone $(12.4 \%)$ came third (Table 3). These crops are dictated by the natural and climatic conditions, and the quality of the soil in the countries in question.

Table 3. The structure of organic agricultural production in Hungary and Poland in 2019.

\begin{tabular}{|c|c|c|c|c|}
\hline \multirow{2}{*}{ Crops } & \multicolumn{2}{|c|}{ Hungary } & \multicolumn{2}{|c|}{ Poland } \\
\hline & Tons & $\%$ & Tons & $\%$ \\
\hline cereals for the production of grain & 101,473 & 49.6 & 271,901 & 41.0 \\
\hline rye and winter cereal mixtures & 4614 & 2.3 & 103,480 & 15.6 \\
\hline barley & 5969 & 2.9 & 5428 & 0.8 \\
\hline oats and spring cereal mixtures & 3149 & 1.5 & 62,652 & 9.4 \\
\hline grain maize and corn-cob-mix & 22,940 & 11.2 & 17,031 & 2.6 \\
\hline rice & 2286 & 1.1 & 0 & 0.0 \\
\hline dry pulses and protein crops for the production of grain & 3963 & 1.9 & 25,567 & 3.9 \\
\hline root crops & 7040 & 3.4 & 17,069 & 2.6 \\
\hline fresh vegetables & 23,815 & 11.6 & 70,398 & 10.6 \\
\hline
\end{tabular}


Table 3. Cont.

\begin{tabular}{|c|c|c|c|c|}
\hline \multirow{2}{*}{ Crops } & \multicolumn{2}{|c|}{ Hungary } & \multicolumn{2}{|c|}{ Poland } \\
\hline & Tons & $\%$ & Tons & $\%$ \\
\hline strawberries & 55 & 0.0 & 7443 & 1.1 \\
\hline fruits from temperate climate zones & 24,353 & 11.9 & 82,460 & 12.4 \\
\hline grapes & 5109 & 2.5 & 279 & 0.0 \\
\hline summary & 204,766 & 100 & 663,708 & 100,0 \\
\hline
\end{tabular}

The organic agricultural policy in Poland and Hungary contributed to the increase in the income of the inhabitants and thus increased their standard of living. However, at the same time, it increased social differences in the countryside, and the price of arable land increased several times. The main problem that arises with this policy in Poland and Hungary is the lack of a correct economic analysis of individual investments. Unjustified investments in many farms often led them to a difficult financial situation and liquidation of small processing plants operating on the local market [29,30].

The organic production sector in Poland and Hungary will be covered by the new legal framework from the beginning of 2022, when Regulation (EU) 2018/848 of the European Parliament and of the Council of 30 May 2018 on organic production and labeling of organic products will enter and repeal the Council Regulation (EC) No. 834/2007 (Journal of Laws UE L 150 p. 1 of 14.6.2018) [31]. On its basis, national action plans are developed, defining tasks aimed at developing organic farming. To support the operation of this sector in Poland and Hungary, areas have been identified that should be particularly addressed by the Ministries of Agriculture and their subordinate or supervised units. It is [29,32,33]:

(1) Knowledge transfer. Further substantive support for producers is planned, which should be related to advisory activities, showing good practices, and conducting scientific research aimed at solving current problems arising in organic farming. On the other hand, to encourage consumers to purchase organic products, it is necessary to conduct ongoing information, education, and promotion activities, which will introduce the principles of organic production and its benefits for consumers, and popularize the organic production logo of the European Union.

(2) Introducing innovation in organic production. Continued support for the organic farming sector is planned through scientific research aimed at solving problems specific to this type of production. It is also crucial that the primary production of organic food takes place in Poland and Hungary and that the production of processed food develops dynamically. The processing of organic products will allow achieving higher income and positively impact building trade relations and increasing employment in rural areas. In addition, it is necessary to help producers join groups, which will strengthen their position in the supply chain, raise the level of production and allow them to better respond to market demand.

(3) Support for organic producers. Organic producers should have easier access to funds allocated for investments on the farm through additional bonuses in their applications for subsidies. These investments are necessary for the development and enhancement of the competitiveness of the Polish and Hungarian organic farming sectors. In addition, support should be provided to compensate for costs related to control and certification.

(4) Increasing confidence in the organic farming system. Ongoing supervision over the compliance of organic production with its principles, objectives, and labeling of these products is planned. 


\subsection{Study Design}

The research applied the method of a diagnostic survey with the use of the direct questionnaire technique. The study was conducted using the Paper and Pencil Interview (PAPI) technique. An original questionnaire was developed. The questionnaire contained nine research questions and additional questions defining the sociodemographic characteristics of the farmers. The questionnaire contained three sections: characteristics of farms, motives and barriers to establishing organic farms, and demographics, but the article only focuses on two issues. In the prepared questionnaire, a Likert scale was opted for, as it allows mathematical computations on variables measured on an interval scale. The importance of individual motives and barriers to farmers was measured on a scale of 1 to 5 , where, where 1 meant "it does not matter", 2 meant "it has little importance, 3 meant "it is of medium importance", 4 meant "it is important" and 5 meant "it is crucial".

The research was carried out in 2017-2019 among 400 Polish and 400 Hungarian farmers running organic farms.

The Statistica 13.1 PL software was used for statistical calculations. The differences between the motives and barriers of running organic farms by Polish and Hungarian farmers were examined using discriminant analysis because it decides which independent variables (predictors) best divide a given set of cases into naturally occurring groups, described by a qualitative dependent variable. It is a method of multivariate data analysis. This technique is an extremely effective tool for classification issues and data mining. Discriminant analysis examines the differences between groups based on a set of selected independent variables using the formula [34]:

$$
\left(\vec{x}-\vec{\mu}_{0}\right)^{T} \sum_{0}^{-1}\left(\vec{x}-\vec{\mu}_{0}\right)+\ln \left|\sum_{0}\right|-\left(\vec{x}-\vec{\mu}_{01}\right)^{T} \sum_{1}^{-1}\left(\vec{x}-\vec{\mu}_{1}\right)-\ln \left|\sum_{1}\right|>T
$$

where:

$w_{i}$ regression coefficients,

$\vec{\mu}_{k}$ mean parameters,

$\sum_{k}$ covariance,

$T$ constant.

It was tested that the matrices of variance of variables are homogeneous in groups and that the variables have a normal distribution. Slight variations were not that important due to the large size of the groups. The differences in the mean values where the probability of randomness was lower than 0.05 were considered statistically significant.

The research also used the method of analyzing statistical data collected in the Eurostat database [20]. Statistical data was compiled using single-base and chain indices [35]:

$$
i_{\frac{t}{0}}=\frac{y_{t}}{y_{0}} \cdot 100
$$

and

$$
i_{t-1}=\frac{y_{t}}{y_{t-1}} \cdot 100
$$

where:

$i_{\frac{t}{0}}$-single-base index

$i_{\frac{t}{t-1}}$-chain index

$y_{0}$-base-period phenomenon

$y_{t}$-phenomenon during the period considered

$y_{t-1}$ - phenomenon in the period immediately preceding the period under study. 


\section{Results}

In empirical research, farmers were asked about the motives for setting up organic farms. The discriminant function model included 5 out of 8 assessed motives. The model did not include the following motives: the desire to produce high-quality products, healthy food production, and tradition (Table 4).

Table 4. Motives for establishing and running organic farms.

\begin{tabular}{|c|c|c|c|c|c|c|}
\hline \multirow{2}{*}{ Factor } & \multicolumn{6}{|c|}{ Model of Discriminant Analysis: Wilks's $\lambda: 0.238 ; \mathrm{F}(8.791)=316.89 ; p<0.001$} \\
\hline & Wilks's $\lambda$ & F & $p$ & Tolerance & Poland $p=0.5$ & Hungary $p=0.5$ \\
\hline favorable location & 0.303 & 216.940 & $<0.001 *$ & 0.952 & 5.349 & 2.857 \\
\hline subsidy/political support & 0.285 & 155.519 & $<0.001$ * & 0.937 & 4.817 & 2.701 \\
\hline willingness to innovate & 0.257 & 63.498 & $<0.001 *$ & 0.782 & 3.111 & 1.643 \\
\hline willingness to protect nature & 0.243 & 18.422 & $<0.001 *$ & 0.776 & 2.265 & 1.474 \\
\hline fashion for organic products & 0.243 & 16.935 & $<0.001$ * & 0.973 & 1.566 & 2.055 \\
\hline healthy food production & 0.239 & 3.167 & 0.076 & 0.912 & 2.184 & 1.875 \\
\hline $\begin{array}{c}\text { desire to produce } \\
\text { high-quality products }\end{array}$ & 0.238 & 0.364 & 0.546 & 0.921 & 0.524 & 0.478 \\
\hline tradition & 0.243 & 0.025 & 0.874 & 0.970 & 6.864 & 6.894 \\
\hline constant & & & & & -34.785 & -47.894 \\
\hline
\end{tabular}

${ }^{*}$ Level of significant difference at $p<0.050$. Source: own study based on the research.

The model achieved the most significant discriminating power at the location of farms $(\mathrm{F}=216.940)$, away from roads with heavy traffic and away from dust emitters, metalbearing waste dumps, large animal farms producing slurry, and other sources of pollution. At $p<0.001$, this motive is significantly more critical for Polish farmers than for Hungarian farmers. An essential condition for establishing and running organic farms $(F=155.519)$ is the possibility of receiving higher subsidies than in the case of conventional farms. Polish farmers pay attention to this motive more often than Hungarian ones. The motive to introduce innovations to one's farm, which enables the improvement of the quality and health properties of the produced crops, also achieved a high discriminatory power $(\mathrm{F}=63.498)$. In this case, this motive is also significantly more critical for Poles than for Hungarians. The willingness to produce food that uses natural resources more economically and exposes the environment to pollution to a lesser extent than conventional agriculture $(\mathrm{F}=18.422)$ is another factor pointed out by the surveyed farmers. A significantly higher dimension of the classification function was also achieved in this case among Polish farmers. Definitely, the lowest value of $\mathrm{F}=16.935$ was observed in the case of the fashion for organic products. Importantly, this motive is significantly more critical for Hungarian farmers than Polish farmers (Table 4).

In the second stage of the research, farmers were asked about the barriers to establishing organic farms. The discriminant function model included 6 out of 7 barriers that were assessed. The model did not include the barrier-high production costs (Table 5).

When analyzing the barriers that make the establishment of organic farms the most difficult, it was indicated that the highest value of $\mathrm{F}=298.083$ was achieved by the factor related to the farm's adjustment to the requirements of the European Union in the field of organic farming. This barrier is significantly more critical for Hungarians than Poles. The discriminant function also achieved high values for the barrier associated with using unique, organic plant protection products $(\mathrm{F}=209.939)$. In this case, the classification function also achieved almost a two times higher value for Hungarian than Polish farmers. On the other hand, using only natural fertilizers $(\mathrm{F}=37.886)$ is a significantly more critical barrier for Poles than Hungarians, as in the case of the barrier associated with obtaining lower yields in organic farming than conventional farming $(\mathrm{F}=26.967)$. The discriminatory 
function was significantly lower for the barrier of the lack of adequate counseling for farmers who want to run an organic farm $(F=7.647)$. The surveyed farmers from Hungary pronounced this problem significantly more than those from Poland. On the other hand, the model achieved the lowest discriminatory power at the barrier of a high degree of bureaucracy $(F=5.007)$, which disturbs Polish farmers more than Hungarian farmers (Table 5).

Table 5. Barriers to establishing and running organic farms.

\begin{tabular}{|c|c|c|c|c|c|c|}
\hline \multirow{2}{*}{ Factor } & \multicolumn{6}{|c|}{ Model of Discriminant Analysis: Wilks's $\lambda: 0.238 ; \mathrm{F}(8.791)=316.89 ; p<0.001$} \\
\hline & Wilks's $\lambda$ & $\mathbf{F}$ & $p$ & Tolerance & Poland $p=0.5$ & Hungary $p=0.5$ \\
\hline adaptation to EU requirements & 0.295 & 298.083 & $<0.001 *$ & 0.912 & 4.137 & 7.740 \\
\hline $\begin{array}{l}\text { use of special plant protection } \\
\text { products }\end{array}$ & 0.272 & 209.939 & $<0.001$ * & 0.918 & 3.345 & 6.395 \\
\hline application of natural fertilizers & 0.225 & 37.886 & $<0.001$ * & 0.800 & 2.417 & 1.510 \\
\hline low yields & 0.222 & 26.967 & $<0.001 *$ & 0.762 & 0.795 & 0.036 \\
\hline no proper advice & 0.217 & 7.647 & $0.006^{*}$ & 0.593 & 1.548 & 2.013 \\
\hline $\begin{array}{c}\text { high degree of } \\
\text { bureaucracy/certification costs }\end{array}$ & 0.216 & 5.007 & $0.026^{*}$ & 0.945 & 1.748 & 1.459 \\
\hline high production costs & 0.215 & 0.630 & 0.428 & 0.592 & 0.994 & 0.855 \\
\hline constant & & & & & -21.957 & -37.947 \\
\hline
\end{tabular}

* Level of significant difference at $p<0.050$. Source: own study based on the research.

\section{Discussion}

Analyses and studies concerning the possibilities of developing organic farming in the world indicate that this is a permanent trend, and the area of organic agricultural land will systematically increase in the following years $[22,36,37]$. The dynamic development of organic farming in the EU results mainly from legal regulations and extensive financial support [38]. Organic production has been identified under the Biodiversity Strategy and the From Field to Table Strategy as an agricultural production sector implementing the European Union's transformation policy for sustainable management. A target was also set to achieve at least $25 \%$ of agricultural land in the EU in the organic farming system by 2030 [29,32]. Jóźwiak [26] indicated the development of organic food production as one of the development paths for Hungarian agriculture. However, it must pay off to switch from conventional to organic farms for this trend to continue among farmers. The production of bio-food is time-consuming and labor-intensive, but it can play a positive role in alleviating rural unemployment by managing the surplus of labor [22,39-41].

The conducted research is of great practical importance. It indicates the main motives of Polish and Hungarian farmers deciding on organic production, and their fears and the main aspects that may inhibit such a decision. This information is vital for policymakers, especially regarding the instruments that need to be put in place to minimize the number of farmers who wish to leave the organic sector.

The development of organic farming is favored by such factors as a low-polluted environment, a high share of protected areas, and subsidies to organic farming and agrienvironmental activities undertaken by farmers [22,40,41]. In Poland, Hungary, and many other countries, integration with the EU has created more significant opportunities to support organic farming [42] financially. One can see here a high agreement with the statements obtained during the polls. Farmers from Poland and Hungary considered the possibility of obtaining co-financing as one of the most important benefits of establishing and running organic farms. Furthermore, the research conducted by Brodzińska [43] among 399 beneficiaries of agri-environmental (PR) programs who received support for the implementation of the organic farming package in the Warmian-Masurian Voivodeship 
showed that the primary determinant of the development of organic farming is the level of financial support. Similar results were obtained by Batyk [40], who surveyed 48 organic farms. The main reason for switching the activity to the organic management system given by the surveyed respondents was the willingness to subsidize organic production. The possibility of obtaining financial support from the EU was assessed as one of the most important benefits of organic agricultural production in the Miś and Zajac surveys [44]. "New organic farmers" are more pragmatic and business-oriented, and economic incentives are important to them [45-48]. On the other hand, Kis's [49] research shows that Hungarian farmers decide to set up organic farms, apart from economic reasons, also out of personal beliefs, namely that such production protects the natural environment. According to Hungarian farmers, technical conditions, i.e., the lack of machines, are also conducive to organic farms' development.

However, Brodzińska [43] pointed out that withholding subsidies for organic farming may drastically reduce its scale, as only $56.4 \%$ of organic farms generate income from the sale of agricultural produce and could cope with the market after the support is withdrawn. According to the experts who prepared the IRWIR PAN report [50], approximately $30-40 \%$ of organic farms will remain on the market due to the suspension of financing. This thesis is also confirmed by the study by Łuczek and Kalinowski [13]. Almost threequarters of the farmers surveyed declared that they would cease organic production lacking support. There were mainly two types of farms-mixed and pasture farms, with the lowest production profitability.

Both Poland and Hungary show a gradual increase in organic production. The exception was in 2015. This was caused by the changing perspective of EU subsidies for 2014-2020. It reduced the number of producers for the first time in many years in 2014 [21,51]. For example, in Poland, in 2014, new conditions for granting green payments were defined. The requirement to link organic production with the market led to a decrease in the number and area of organic farms, as farmers did not have time to prepare for changes in the requirements imposed in PROW 2014-2020 [13,52].

Brodzińska [43] also noted that the support system under PROW 2014-2020 does not support the marketization of organic farms. In her opinion, the system of financial support for organic agricultural products placed on the market would allow creating a market for organic products $[43,52,53]$. A good example is Germany and its care for local markets of organic products. Small farms dominate both Poland and Hungary. They should produce for the local market (local shops, fairs, bazaars, events), for the needs of agritourism, and for specific recipients, e.g., restaurants and other mass catering facilities [40,54]. Tandon et al. [55] and Wojciechowska-Solis and Soroka [56] also point out that education should encourage producers to sell organic food in their stores. One of the activities in the Framework Action Plan for Organic Food and Farming in Poland for 2021-2027 is information about distribution channels, under which new forms of sale are to be promoted, e.g., purchasing cooperatives, portals facilitating the sale of organic products via the Internet, or socially supported agriculture [29].

Food plays a significant role in the development of agritourism. The organic farm's food production system has high hopes for gaining more customers, as organically produced products attract buyers confident that the food offered is of natural origin and organic [53,57-59].

Another opportunity for organic farming in Poland and Hungary is further investments in vegetable production and horticulture, which is in great demand in EU countries, the USA, and Japan [44,54]. According to this article's research, in Hungary, the production of fruit from temperate climatic zones was second $(11.9 \%)$, and of organic vegetablesthird $(11.6 \%)$. On the other hand, in Poland, the production of fresh vegetables came third $(12.4 \%)$, and fruit production was fourth $(10.6 \%)$.

However, Pondel [60] examined the motives for managing organic methods among 196 agricultural producers from the Greater Poland Voivodeship. The most important motive was the concern for family health. Concern for the condition of the soil and the 
will to live to harmonize with nature were in a high third and fourth place. These results correspond to those presented in Table 4 with the motive "the will to protect nature". Other studies conducted on a group of 99 owners of agri- and eco-tourism farms showed that organic activities' benefits are environmental protection and care [57].

Demand segmentation is taking place globally, and the group of the so-called "green consumers" who prefer a healthy lifestyle and organic products, including food, is growing [61-65]. It responds to the growing health awareness of society $[21,55,65,66]$, society getting richer, and the growing popularity of vegan and vegetarian diets [30]. The fashion for organic products was also noticed by the authors surveyed by the article's authors and is considered one of the key motives for establishing and running organic farms. Another factor contributing to the growing popularity of organic products is their easier availability for the average customer, e.g., by increasing the offer of bioproducts in hypermarkets or discount chains, displaying them on shelves, or creating entire alleys with bioproducts [30]. As part of the Framework Action Plan for Organic Food and Farming in Poland for 2021-2027, Poland plans extensive information and promotional activities aimed at promoting and perpetuating knowledge about organic farming, environmental and social benefits of organic production, informing consumers about the features and benefits of such food, and their consolidation in consciousness. These will be publications in the press and the Internet, cooperation with television, distribution of information materials, participation in meetings and conferences, and fairs and exhibitions [29].

A tradition was not included in the model of motives for establishing and running organic farms. Furthermore, in the opinion of the farmers surveyed by Miś and Zając [44], maintaining family traditions became the least significant benefit of organic farming. However, it is worth adding that farmers who also conducted agritourism significantly higher than other respondents assessed the significance of this answer.

The respondents recognized adaptation to EU requirements as the most crucial barrier to establishing and running organic farms. Farmers surveyed by Miś and Zajacc [44] and Dezsény and Drexler [51] also pointed out the necessity to adapt to EU requirements and the related difficulties. Still, in their opinion, it was an average barrier. Similar conclusions were drawn from a US study [67] which found that regulatory issues are the most common reason for organic farmers returning to conventional farming. On the other hand, according to the research by Kołoszko-Chomentowska and Stalgiene [68], market uncertainty is a significant barrier to the development of organic farming in Poland and Hungary.

Low yields were another obstacle that the respondents pointed out. Research by Szlovicsák [69], Kociszewski [70], and Pelletier et al. [71] certified organic farms placed this production barrier in one of the first places [69-71]. Łuczka and Kalinowski [13] and Hungarian researchers [24] also pointed out that low yields may contribute to the fact that farmers perceive organic farming as risky. The opportunities to reduce this barrier are innovative solutions concerning new plant protection techniques and sources of fertilizers. The possibility of achieving higher income and reducing the risk of unprofitability in producing primary organic food is provided by its processing. Developing processing also positively affects increasing employment in rural areas and building trade relations [29].

According to the respondents, one of the barriers to establishing and running organic farms was the lack of proper advice and a high degree of bureaucracy. Szlovicsák [69] and Gombos [72] described similar opinions. The research carried out among organic farms showed that, although agricultural advisory centers conduct educational activities for farmers, they do not receive support in advertising and distribution. The second significant problem that farmers emphasized was bureaucracy and the lack of support in keeping the necessary documentation. Knowledge transfer is one of the four main activities in the Framework Action Plan for Food and Organic Farming in Poland for 2021-2027. Agricultural Advisory Centers must have current and specialist knowledge about organic farming and make it accessible to producers [29].

One of the barriers to establishing and running organic farms, namely high production costs, was not included in the discriminant function model. These results are consistent 
with those presented by Batyk [40] and Frank et al. [73], with information that there are much lower material and money inputs for agricultural production in the organic way of farming. The production costs were most likely not that important because both Polish and Hungarian agriculture is not yet so developed and innovative. It does not use advanced machinery and plant protection products. It is more labor-intensive, but farmers do not include it in the costs for two reasons. They only employ seasonal workers during the harvest season, and most often, they do it illegally, so they do not have to pay social security, health insurance, or taxes. Moreover, wages in agriculture in Poland and Hungary are very low. In Polish accounting, the own work of the owners or their family members is not included in the costs [40].

\section{Conclusions}

The article focuses on the opinions of Polish and Hungarian farmers on the motives and barriers to establishing and running organic farms. However, many of these considerations are relevant to the broader debate about the development of organic farming in other countries.

1. The main motives for setting up organic farms in Poland and Hungary are the favorable location of the farm, the possibility of receiving funding, the willingness to introduce innovation in one's own farm, environmental protection, and the fashion for organic products.

2. The main barriers to establishing the farms mentioned above in the two studied countries are the need to adapt their farm to EU requirements, the need use unique plant protection products and only natural fertilizers, low yields, a lack of appropriate advice, and a high degree of bureaucracy.

3. Further education of farmers is necessary for organic farming to develop by creating a network of demonstration farms and processing plants, developing information and promotion materials with good practices, and organizing courses, industry meetings, and conferences at which the results of research related to organic farming will be presented. Farmers should benefit from free advice from agricultural advisors who will help them adapt their farms to EU requirements. An important aspect is improving the quality of the regulations and simplifying the administrative burden related to organic farming.

4. National authorities, local governments, and farmers should also actively promote organic farming to consumers, which will bring benefits to the entire economy.

5. In addition, it is necessary to diversify distribution channels, e.g., creating organic food markets, where consumers can buy fresh products directly from the producer for a lower price, and the farmer has a permanent outlet, the creation of purchasing cooperatives, socially supported farming systems, and online sales networks. However, it is vital to ensure that such places do not become a market for agricultural produce of unknown origin.

6. Networking with the various actors in the organic food sector is recommended. Collaborative integration is an opportunity to exchange information, expand knowledge and solve problems together. Farmers have to deepen their knowledge and skills regarding production technology, market conditions (e.g., new forms of sales and distribution channels, promotional activities), and formal and legal procedures and strengthen their competitive advantage over other market participants.

Author Contributions: Conceptualization, A.M.-K. and B.S.; methodology, A.M.-K., software A.M.-K.; validation A.K. and A.M.-K.; formal analysis A.M.-K. and A.K.; investigation, A.K.; resources A.K. and A.M.-K.; data curation, A.K. and A.M.-K.; writing—original draft preparation A.K and A.M.-K.; writing-review and editing A.M.-K., B.S. and A.K.; visualization, B.S. and A.K.; supervision, B.S.; project administration, B.S.; funding acquisition, B.S. All authors have read and agreed to the published version of the manuscript. 
Funding: This work was financed by profit from postgraduate studies: Agricultural studies for non-agricultural specializations.

Institutional Review Board Statement: All procedures performed in this study were in accordance with the ethical standards of the Polish Committee on Ethics in Science and the 1964 Declaration of Helsinki.

Informed Consent Statement: Informed consent was obtained from all subjects involved in the study.

Data Availability Statement: Not available.

Conflicts of Interest: The authors declare that they have no conflict of interest to disclose.

\section{References}

1. Palupi, E.; Jayanegara, A.; Ploeger, A.; Kahl, J. Comparison of Nutritional Quality between Conventional and Organic Dairy Products: A Meta-Analysis. J. Sci. Food Agric. 2012, 92, 2774-2781. [CrossRef]

2. Suwala, G. Żywność Ekologiczna w świadomości Polaków. Zesz. Nauk. Akad. Ekon. Krakowie 2006, 705, 57-75.

3. Talwar, S.; Jabeen, F.; Tandon, A.; Sakashita, M.; Dhir, A. What Drives Willingness to Purchase and Stated Buying Behaviour Toward Organic Food? A Stimuluse Organisme Behaviore Consequence (SOBC) Perspective. J. Clean. Prod. 2021, $293,125885$. [CrossRef]

4. Central Statistical Office in Poland. Available online: bdl.stat.gov.pl/BDL/dane/podgrup/tablica (accessed on 6 July 2021).

5. Zdrojewska, I. The Report on Organic Farming in Poland in 2017-2018; IJHARS (Agricultural and Food Quality Inspection): Warsaw, Poland, 2019; pp. 24-37.

6. FiBL. Organic Food in Poland and Hungary in 2000-2020; The Statistics.FiBL.org website maintained by the Research Institute of Organic Agriculture (FiBL): Frick, Switzerland, 2021; Available online: www.fao.org/faostat/en/?\#data/QC (accessed on 6 July 2021).

7. Central Statistical Office in Hungary. Available online: www.ksh.hu/stadat_files/mez/en/mez0038.html (accessed on 6 July 2021).

8. Danner, H.; Menapac, L. Using Online Comments to Explore Consumer Beliefs Regarding Organic Food in German-Speaking Countries and the United States. Food Qual. Prefer. 2020, 83, 103112. [CrossRef]

9. Boizot-Szantai, C.; Hamza, Q.; Soler, L.G. Organic Consumption and Diet Choice: An Analysis Based on Food Purchase Data in France. Apettite 2017, 117, 17-18. [CrossRef]

10. Dash, M.; Samantaray, A.; Dash, M. Consumer's Perception Towards Organic Food Products. Int. J. Eng. Manag. Res. 2014, 4, 110-113.

11. Bryla, P. Organic Food Consumption in Poland: Motives and barriers. Appetite 2016, 105, 737-746. [CrossRef] [PubMed]

12. Siepmann, L.; Nicholas, K.A. German Winegrowers' Motives and Barriers to Convert to Organic Farming. Sustainability 2018, 10, 4215. [CrossRef]

13. Łuczka, W.; Kalinowski, S. Barriers to the Development of Organic Farming: A Polish Case Study. Agriculture 2020, 10, 536. [CrossRef]

14. Hermaniuk, T. Organic Food Market in Poland-Main Characteristics and Factors of Development. Sci. Ann. Econ. Bus. 2016, 63, 135-147. [CrossRef]

15. Zorn, I.; Lippert, C.; Dabbert, S. An Analysis of the Risks of Non-Compliance with the European Organic Standard: A Categorical Analysis of Farm Data from A German Control Body. Food Control 2013, 30, 692-699. [CrossRef]

16. Racula, A. Analysis of Organic Farming Sector in Romania. Int. J. Comp. Manag. 2012, 13, 449-455.

17. Barabanova, Y.; Zanoli, R.; Schlüter, M.; Stopes., C. Transforming Food E Farming, an Organic Vision for Europe in 2030; IFOAM EU Group: Brussels, Belgium, 2015; pp. 3-31.

18. Blanco-Penedo, I.; Sjöström, K.; Jones, P.; Krieger, M.; Duval, J.; Soest, F.; Sundrum, A.; Emanuelson, U. Structural Characteristics of Organic Dairy Farms in Four European Countries and Their Association with the Implementation of Animal Health Plans. Agric. Syst. 2019, 173, 244-253. [CrossRef]

19. Casolani, N.; Nissi, E.; Giampaolo, A.; Liberatore, L. Evaluating the Effects of European Support Measures for Italian Organic Farms. Land Use Policy 2021, 10, 105225. [CrossRef]

20. Eurostat, Organic Crop Area by Agricultural Production Methods and Crops (from 2012 Onwards). Available online: ec.europa. eu/eurostat/databrowser/view/org_cropar/default/table?lang=en (accessed on 15 April 2021).

21. Drabarczyk, K.; Wrzesińska-Kowal, J. Rozwój Rolnictwa Ekologicznego w Polsce. Ekon. Organ. Gospod. Żywnościowej 2015, 111, 19-31. [CrossRef]

22. Brzezina, N.; Biely, K.; Helfgott, A.; Kopainsky, B.; Vervoort, J.; Mathijs, E. Development of Organic Farming in Europe at the Crossroads: Looking for the Way Forward through System Archetypes Lenses. Sustainability 2017, 9, 821. [CrossRef]

23. Gombos, M. The Possibilities and Challenges of Sustainable Agriculture in Hungary-Searching for Pathways for a Feasible Conversion in the Agricultural Sector; Aalborg University: Aalborg, Denmark, 2017; pp. 11-49.

24. ÖMKi. Összefoglaló. In Az Ökológiai Gazdálkodás Hazai Helyzete-Hol Tartunk a Fenntarthatóság Felé Vezető Úton? ÖMKi: Budapest, Hungary, 2017; p. 8. 
25. Liu, C.; Zheng, Y.; Cao, Z. An Analysis of Factors Affecting Selection of Organic Food: Perception of Consumers in China Regarding Weak Signals. Appetite 2021, 161, 10145. [CrossRef] [PubMed]

26. Jóźwiak, W. Rolnictwo Węgierskie Poszukuje Drogi Rozwoju. Zagadnienia Ekon. Rolnej 2012, 4, 123-130.

27. Kaliński, J. Transformations of the Spatial Structure of Peasant Farms in Poland after 1918. Kwart. Kol. Ekon. Spotecznego. Studia I Pr. 2018, 3, 121-143.

28. Fałkowski, J. Zamiany Liczby Gospodarstw Rolnych w Polsce w Okresie Transformacji. Gospod. Nar. 2010, 237, 89-108. [CrossRef]

29. Ministerstwo Rolnictwa i Rozwoju Wsi. Ramowy Plan. Działań dla Żywności i Rolnictwa Ekologicznego w Polsce na Lata 2021-2027; Ministerstwo Rolnictwa i Rozwoju Wsi: Warsaw, Poland, 2021; pp. 2-12.

30. Rynek Żywności Bio i Kosmetyków Naturalnych w Polsce 2019. Analiza Rynku i Prognozy Rozwoju na Lata 2019-2024; PMR Market Experts: Kraków, Poland; Available online: mypmr.pro/products/19073 (accessed on 6 July 2021).

31. Regulation (EU) 2018/848 of the European Parliament and of the Council of 30 May 2018 on organic production and labelling of organic products and repealing. Council Regulation (EC) No 834/2007 (Journal of Laws UE L 150 p. 1 of 14.6.2018) (Rozporządzenie Parlamentu Europejskiego i Rady (UE) 2018/848 z dnia 30 maja 2018 r. w sprawie produkcji ekologicznej $i$ znakowania produktów ekologicznych i uchylające rozporządzenie Rady (WE) nr 834/2007) (Dz. Urz. UE L 150 str. 1 z 14.6 .2018 r.). 30 May.

32. Horváth, D.; Szúcs, V. AZ Európai Bizottság Viziója a Fenntartható Mezőgazdaságról és Élelmiszeriparról, Avagy mit Tartalmaz a Termőföldtől az Asztalig Stratégia; Namzeti Agrargazdasagi Kamara: Budapest, Hungary, 2021; pp. 1-5.

33. Vidékfejlesztési Minisztérium. Nemzeti Akcióterv az Ökológiai Gazdálkodás Fejlesztéséért, Vidékfejlesztési Minisztérium; Vidékfejlesztési Minisztérium: Budapest, Hungary, 2014; pp. 3-4.

34. Manly, B.F.J. Multivariate Statistical Methods: A Primer; Chapman and Hall/CRC Press: Boca Raton, FL, USA, $2005 ;$ pp. $156-183$.

35. Sobczyk, M. Statystyka; Wydawnictwo Naukowe PWN: Warszawa, Poland, 2004; pp. 325-344.

36. Kukuła, K.; Luty, L. The Ranking of EU Countries Due to Selected Indicators Characterizing Organic Farming. Metod. Ilościowe Bad. Ekon. 2015, XVI, 225-236.

37. Golinowska, M.; Kruszyński, M.; Janowska-Biernat, J. Tendencje w Rozwoju Rolnictwa Ekologicznego na Świecie w Latach 1999-2012. J. Agric. Eng. Res. 2013, 58, 155-161.

38. Smoluk-Sikorska, J. The Condition of Organic Farming and Market of Its Products in the European Union. J. Agric. Rural Dev. 2010, 4, 87-95.

39. Turczak, A. Perspektywy Rozwoju Rolnictwa Ekologicznego w Polsce. Zesz. Nauk. Firma Rynek 2014, 1, 59-72.

40. Batyk, I.M. Działalność Pozarolnicza Gospodarstw Ekologicznych w Województwie Warmińsko-Mazurskim. Infrastruct. Ecol. Rural. Areas 2012, 2, 43-52. (In Polish)

41. Erdelyi, O. Sustainability and Organic Farming in the Light of Conventions Theory. The Example of the Hungarian Organic Sector; Stockholm Environment Institute: Stockholm, Sweden, 2010; pp. 14-17.

42. Luty, L. Rolnictwo Ekologiczne-Rozwój w Wybranych Krajach Unii Europejskiej. Metody Ilościowe w Badaniach Ekonomicznych 2019, XVII, 65-74.

43. Brodzińska, K. Organic Farming-Trends and Directions of Changes. Sci. J. Wars. Univ. Life Sci. Probl. Word Agric. 2014, 14, 27-36.

44. Miś, T.; Zając, D. Problemy Rozwoju Rolnictwa Ekologicznego w Regionie o Rozdrobnionej Strukturze Obszarowej. Zagadnienia Doradz. Rol. 2017, 2, 47-61.

45. Heinze, S.; Vogel, A. Reversion from Organic to Conventional Agriculture in Germany: An Event History Analysis. Ger. J. Agric. Econ. 2017, 66, 13-25.

46. Läpple, D.; Kelley, H. Understanding the Uptake of Organic Farming: Accounting for Heterogeneities among Irish Farmers. Ecol. Econ. 2013, 88, 11-19. [CrossRef]

47. Flaten, O.; Lien, G.; Ebbesvik, M.; Koesling, M.; Valle, P.S. Do the New Organic Producers Differ from the 'Old Guard'? Empirical Results from Norwegian Dairy Farming. Renew. Agric. Food Syst. 2006, 21, 174-182. [CrossRef]

48. Darnhofer, I.; Schneeberger, W.; Freyer, B. Converting or Not Converting to Organic Farming in Austria: Farmer Types and Their Rationale. Agric. Hum. Values 2005, 22, 39-52. [CrossRef]

49. Kis, S. Results of a Questionnaire Survey of Hungarian Organic Farms. Stud. Agric. Econ. 2007, 106, $124-148$.

50. Jasiński, J.; Michalska, S.; Śpiewak, R. Report IRWIR PAN. Rolnictwo Ekologiczne Czynnikiem Rozwoju Lokalnego. Analiza Wybranych Przypadków; IRWIR PAN: Warszawa, Poland, 2019.

51. Dezsény, Z.; Drexler, D. The Development and State of Organic Ariculture in Hungary. Hungarian Research. OCROFS News 2014, 2, 5-6.

52. Juchniewicz, M.; Nahtman, G. 2018 Standard Results of Farms Covered by the Polish FADN. Part 2. Analysis of Standard Results; Institute of Agricultural and Food Economics: Warsaw, Poland, 2020; pp. 9-12.

53. Smoluk-Sikorska, J.; Łuczka, W.; Kalinowski, S. The State of Organic Food Processing in Poland. In Competitiveness of European Agriculture and Food Sectors, Proceedings of the 26th International Scientific Conference Agrarian Perspectives; Czech University of Life Sciences Prague: Prague, Czech Republic, 2017; pp. 349-354.

54. Domagalska, J.; Buczkowska, M. Organic Farming-Opportunities and Perspectives. Probl. Hig. Epidemiol. 2015, 96, 370-376.

55. Tandon, A.; Jabeen, F.; Talwar, S.; Sakashita, M.; Dhir, A. Facilitators and inhibitors of organic food buying behaviour. Food Qual. Prefer. 2021, 88, 104077. [CrossRef] 
56. Wojciechowska-Solis, J.; Soroka, A. Motives and Barriers of Organic Food Demand among Polish Consumers: A Profile of the Purchasers. Br. Food J. 2017, 119, 2040-2048. [CrossRef]

57. Dąbrowski, D.; Radwańska, K.; Sokół, J.L.; Zbucki, Ł.; Isakova, Y. Czynniki Decydujące o Funkcjonowaniu I Rozwoju Gospodarstw Agroturystycznych w Dolinie Bugu na Przykładzie Województwa Podlaskiego. In Obszary Przyrodniczo Cenne w Rozwoju Turystyki; Jalinik, M., Bakier, S., Eds.; Oficyna Wydawnicza Politechniki Białostckiej: Białystok, Poland, 2020; pp. 166-180. [CrossRef]

58. Vukasovic, T. Consumers' Perceptions and Behaviors Regarding Organic Fruits and Vegetables: Marketing Trends for Organic Food in the Twenty-First Century. J. Int. Food Agribus. Mark. 2016, 28, 59-73. [CrossRef]

59. Trafialek, J.; Czarniecka-Skubina, E.; Kulaitiené, J.; Vaitkeviciene, N. Restaurant's Multidimensional Evaluation Concerning Food Quality, Service and Sustainable Practices: A Cross-National Case Study of Poland and Lithuania. Sustainability 2020, 12, 234. [CrossRef]

60. Pondel, H. Organic Farming in the Opinion of the Farmers from Wielkopolska. J. Agric. Eng. Res. 2006, 51, 139-143.

61. Wang, J.; Shen, M.; Gao, Z. Research on the Irrational Behavior of Consumers' Safe Consumption and Its Influencing Factors. Int. J. Environ. Res. Public Health 2018, 15, 2764. [CrossRef]

62. Kushwah, S.; Dhir, A.; Sagarm, M.; Gupta, B. Determinants of Organic Food Consumption. A Systematic Literature Review on Motives and Barriers. Appetite 2019, 143, 104402. [CrossRef] [PubMed]

63. Truong, V.A.; Lang, B.; Conroy, D.M. Are Trust and Consumption Values Important for Buyers of Organic Food? A Comparison of Regular Buyers, Occasional Buyers, and Non-Buyers. Appetite 2021, 161, 105123. [CrossRef] [PubMed]

64. Soroka, A.; Wojciechowska-Solis, J. Consumer Motivation to Buy Organic Food Depends on Lifestyle. Foods 2019,8 , 581. [CrossRef] [PubMed]

65. Mazurek-Kusiak, A.; Kobyłka, A.; Sawicki, B. Assessment of Nutritional Behavior of Polish Pupils and Students. Br. Food J. 2019, 121, 2296-2308. [CrossRef]

66. Wojciechowska-Solis, J.; Barska, A. Exploring the Preferences of Consumers' Organic Products in Aspects of Sustainable Consumption: The Case of the Polish Consumer. Agriculture 2021, 11, 138. [CrossRef]

67. Sierra, L.; Klonsky, K.; Strochlic, R.; Brodt, S.; Molinar, R. Factors Associated with Deregistration among Organic Farmers in California; University of California SAREP: Davis, CA, USA, 2008; Available online: sarep.ucdavis.edu/sites/g/files/dgvnsk5751/files/ inline-files/2008_Deregistration_factors.pdf (accessed on 12 May 2021).

68. Kołoszko-Chomentowska, Z.; Stalgiene, A. Annals of the Polish Association of Agricultural and Agribusiness Economists. Annals PAaAE 2019, XXI, 215-222. [CrossRef]

69. Szlovicsák, K. (Ed.) Biokultúra Hírlevél. A biogazdálkodók, környezetkímélők és egészségkedvelők tájékoztatója; Magyar Biokultúra Szövetség: Budapest, Hungary, 2017; pp. 5-9.

70. Kociszewski, K. Barriers and Factors Favourable for Functioning of Organic Farms in the Light of Nationwide Questionnaire Survey. Rocz. Nauk. 2014, XVI, 129-134. [CrossRef]

71. Pelletier, J.E.; Laska, M.N.; Neumark-Sztainer, D.; Story, M. Positive Attitudes toward Organic, Local, and Sustainable Foods Are Associated with Higher Dietary Quality among Young Adults. J. Acad. Nutr. Diet. 2013, 113, 127-132. [CrossRef]

72. Gombos, M.; Párdi, P. Transition towards Sustainability in Budapest through the Case of a Degrowth Fueled Social Cooperative; Aalborg University: Aalborg, Denmark, 2016; pp. 5-6.

73. Frank, E.; Berg, M.V.; Decock, C.; Maat, H.; Srivastava, A. Does Organic Farming Provide a Viable Alternative for Smallholder Rice Farmers in India? Sustainability 2018, 10, 4424. [CrossRef] 